COMPETITOR: Jurnal Pendidikan Kepelatihan Olahraga

Volume 13 Number 2 Year 2021

e-ISSN: 2657-0734 \& p-ISSN: 2085-5389

This work is licensed under a Creative Commons Attribution 4.0 International License

\title{
The Increase in $\mathrm{VO}_{2} \mathrm{Max}$ and Passing Using Exercise Small-Sided Game 3 vs 3 and 6 vs 6 On Football Players
}

\author{
Muhammad Fajri Maujud ${ }^{1 *}$, Zainal Afandi $^{2}$, Budiman Agung Pratama ${ }^{3}$ \\ 1,2,3 Postgraduate Program / Nusantara PGRI Kediri University / East Java / Indonesia \\ 1,2,3 Street. KH. Ahmad Dahlan No. 76, Mojoroto, District. Mojoroto, Kediri City, East Java, 64112 \\ 1ajrimaujud46@gmail.com, ${ }^{2}$ zafandis69@unpkediri.ac.id ${ }^{3}$ agung10@unpkediri.ac.id
}

Received: May 02, 2021; Reviewed: May 3, 2021; Accepted: June 5, 2021;

Published: June 22, 2021

\begin{abstract}
The purpose of this study was to determine the increase in vo2max and passing skills using small-sided games 3 vs 3 and 6 vs 6 exercises in soccer players. This study uses a quantitative approach, the type of research is experimental research, the sample used is 51 football players in Trenggalek under-14 who were selected randomly, this research was carried out in Trenggalek district, namely the Siwalan field, Sumbergedong field, and Sumberagung field, the instrument in the study This study uses a multistage fitness test and a passing test in football, data analysis uses the Manova test. The results showed that there was a difference between the small-sided games 3 vs 3 exercise group and the 6 vs 6 small-sided games group to increase vo2max with a sig value. $0.031<0.05$, and there is a difference between the small-sided games 3 vs 3 practice group and the 6 vs 6 small-sided games group to improve passing with a sig value of $0.027<0.05$. It can be concluded that overall small-side game exercises 3 vs 3 and 6 vs 6 can increase vo2max and passing for football players.
\end{abstract}

Keywords: Vo2max; Passing; Small-Sided Game; Football.

\section{INTRODUCTION}

Football is a physical sport which means that all players are required to have excellent physical endurance, the results of studies in football schools throughout Trenggalek Regency show that many players have the poor aerobic capacity, out of 69 players 4 players have an average VO2 max, 7 players have a VO2 max below on average, the rest of the players have a bad VO2 max. Based on this study, many factors may influence it, one of which is the training menu that is not following the sport, considering that each sport has its standard of training criteria to achieve the intended target, so that in coaching and developing athletes it does not cause feelings of boredom to the training program. In soccer, exercise increase aerobic capacity according to research results that small-sided game exercises can increase aerobic capacity for soccer players (Apriliyanto, 
The Increase in $\mathrm{VO}_{2}$ Max and Passing Using Exercise Small-Sided Game 3 vs 3 and 6 vs 6 On Football Players

Muhammad Fajri Maujud ${ }^{1 *}$,Zainal Afandi ${ }^{2}$, Budiman Agung Pratama ${ }^{3}$

Fajrimaujud46@gmail.com

2019; Putra, 2015; Shandy, 2017; Wahyudianto, Setiawan, \& Pratama, 2020). Small-sided games (SSG) are games played on a smaller field, using modified rules and involving fewer players than normal football (Hill-Haas, Dawson, Impellizzeri, \& Coutts, 2011). The use of small-sided games as a special instrument to improve physical condition, develop players' tactics and techniques, increase specificity and training stimulus is indeed very effective in terms of the progress achieved (Kelly \& Drust, 2009). In the practice of small side games, there are several variations including $1 \mathrm{v} 1,2 \mathrm{v} 2,3$ v 34 v 45 v 5 and 6 v 6 with different field sizes (Owen, Twist, \& Ford, 2004).

In the game of football, in addition to good physical condition, players also need qualified techniques, one of the techniques in the game of football is passing. The passing technique in the football game, which is to give feedback to teammates, the goal is not to score goals (Pratama, 2017) in the 3 v 3 small side game exercise, turns out to have an impact on passing techniques that are more frequent than other techniques (Owen et al., 2004). ), another finding states that $3 \times 3$ training is better than $6 \times 6$ in improving physical condition and football technical ability and is recommended to be used to train young players (Katis \& Kellis, 2009). Based on these findings, this study will try to prove and compare the practice of small-sided games $3 \mathrm{v} 3$ and $6 \mathrm{v}$ on vo2max ability and passing ability in football.

\section{METHOD}

In this study using a quantitative approach, the quantitative approach in research is characterized by hypothesis testing and the use of standardized test instruments (Maksum, 2012), the type of research used is experimental research, type experimental research is a way to reveal a relationship between two variables. or more and also to find the effect of one variable on other variables (Maksum, 2012), the sample used was 51 football players in Trenggalek under-14 who were randomly selected, this research was carried out in Trenggalek district namely the Siwalan field, Sumbergedong field, and Sumberagung field, the instrument in this study used a multistage fitness test and a passing test in football (Winarno, 2006), the data analysis in this study used the Multivariate Analysis of Variance (MANOVA) test which was designed to simultaneously test differences in several dependent variables, for this purpose, the form of the hip test The hypothesis used is wilks' $\lambda$. If the results of the Wilks' $\lambda$ analysis show a significant difference, then the analysis is continued by looking at the combination of 
The Increase in $\mathrm{VO}_{2}$ Max and Passing Using Exercise Small-Sided Game 3 vs 3 and 6 vs 6 On Football Players Muhammad Fajri Maujud ${ }^{1 *}$,Zainal Afandi ${ }^{2}$, Budiman Agung Pratama ${ }^{3}$

Fajrimaujud46@gmail.com

differences between groups (Maksum, 2012).

\section{RESULTS AND DISCUSSION}

The results of the pretest and posttest measurements for each exercise group using the passing test and the multistage fitness test can be seen in the table and graph below:

Table 1.

Pretest and Posttest VO2 Max Practice Group Small-Sided Games 3 VS 3

\begin{tabular}{rcccccc}
\hline No & Category & Interval & F & Pretest & \multicolumn{2}{c}{ Posttest } \\
& & & F & F & \% \\
\hline 1 & Excellent & $>55,6$ & 0 & $0 \%$ & 0 & $0 \%$ \\
2 & Above average & $51,7-55,3$ & 0 & $0 \%$ & 0 & $0 \%$ \\
3 & Average & $42,5-51,4$ & 6 & $50 \%$ & 7 & $58 \%$ \\
4 & Below average & $36,6-42,2$ & 3 & $25 \%$ & 5 & $42 \%$ \\
5 & Low & $<36,3$ & 3 & $25 \%$ & 0 & $0 \%$ \\
\hline \multicolumn{2}{r}{ Total } & & $\mathbf{1 2}$ & $\mathbf{1 0 0 \%}$ & $\mathbf{1 2}$ & $\mathbf{1 0 0 \%}$ \\
\hline
\end{tabular}

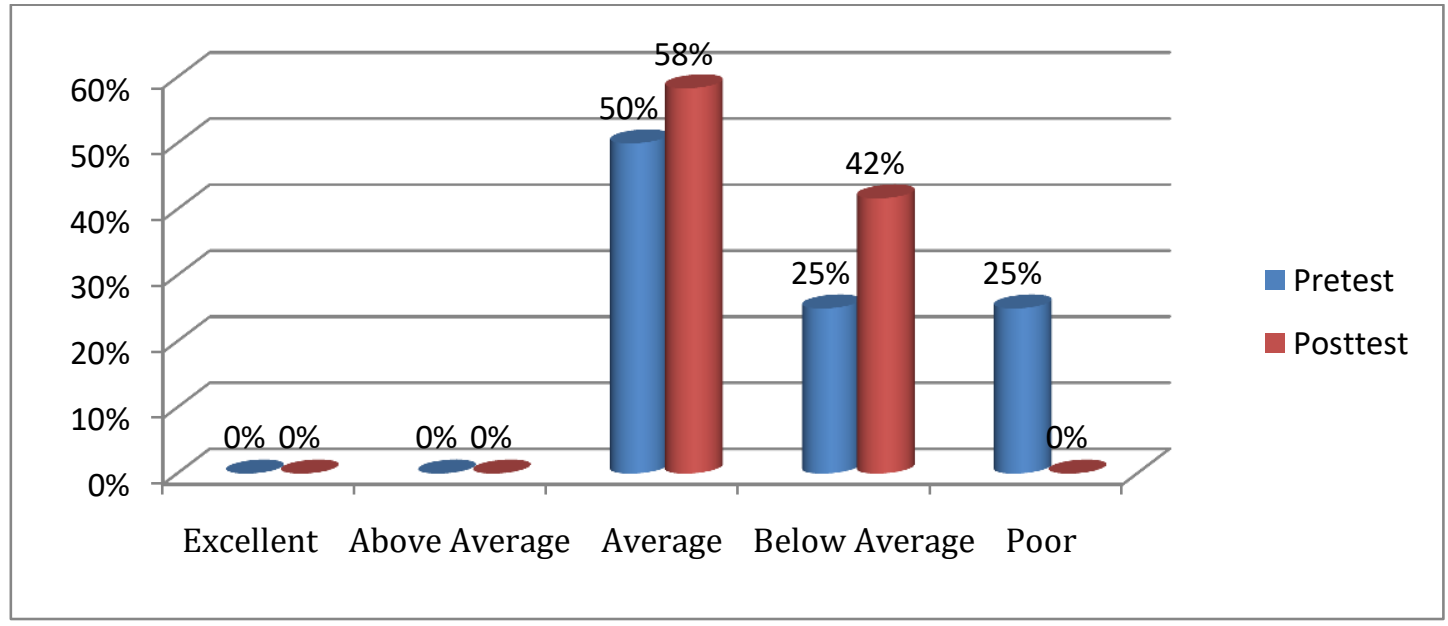

Figure 1.

Graph pretest and posttest VO2max exercise group Small-Sided Games 3 vs 3

Table 2.

Results pretest and posttest Passing Exercise Group Small-Sided Games 3 vs 3

\begin{tabular}{cccccc}
\hline \multirow{2}{*}{ No } & \multirow{2}{*}{ Class Interval } & \multicolumn{2}{c}{ Pretest } & \multicolumn{2}{c}{ Posttest } \\
& & F & \% & F & \% \\
\hline 1 & $13-14$ & 0 & $0 \%$ & 6 & $50 \%$ \\
2 & $11-12$ & 5 & $42 \%$ & 2 & $17 \%$ \\
3 & $9-10$ & 2 & $17 \%$ & 4 & $33 \%$ \\
4 & $7-8$ & 3 & $25 \%$ & 0 & $0 \%$ \\
5 & $5-6$ & 2 & $17 \%$ & 0 & $0 \%$ \\
\hline & Total & $\mathbf{1 2}$ & $\mathbf{1 0 0} \%$ & $\mathbf{1 2}$ & $\mathbf{1 0 0 \%}$ \\
\hline
\end{tabular}


The Increase in $\mathrm{VO}_{2}$ Max and Passing Using Exercise Small-Sided Game 3 vs 3 and 6 vs 6 On Football Players Muhammad Fajri Maujud ${ }^{1^{*}}$, Zainal Afandi ${ }^{2}$, Budiman Agung Pratama ${ }^{3}$

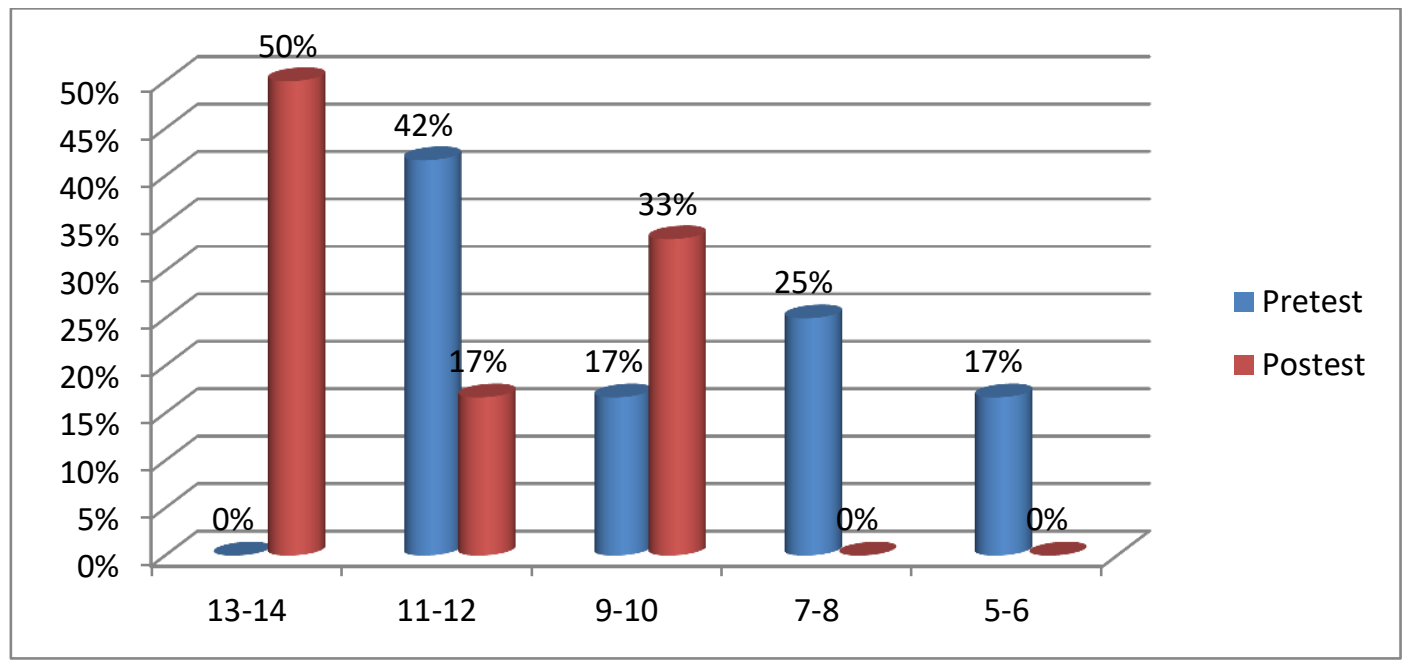

Figure 2.

Graph pretest and posttest Passing Exercise group Small-Sided Games 3 vs 3

Table 3.

Pretest and Posttest VO2Max Practice Group Small-Sided Games 6 VS 6

\begin{tabular}{rcccccc}
\hline No & Category & Interval & F & $\begin{array}{c}\text { Pretest } \\
\text { \% }\end{array}$ & F & $\begin{array}{c}\text { Posttest } \\
\text { \% }\end{array}$ \\
\hline 1 & Excellent & $>55,6$ & 0 & $0 \%$ & 0 & $0 \%$ \\
2 & Above average & $51,7-55,3$ & 0 & $0 \%$ & 0 & $0 \%$ \\
3 & Average & $42,5-51,4$ & 1 & $4 \%$ & 3 & $13 \%$ \\
4 & Below average & $36,6-42,2$ & 3 & $13 \%$ & 11 & $46 \%$ \\
5 & Low & $<36,3$ & 20 & $83 \%$ & 10 & $42 \%$ \\
\hline & & $\mathbf{2 4}$ & $100 \%$ & $\mathbf{2 4}$ & $100 \%$ \\
\hline
\end{tabular}

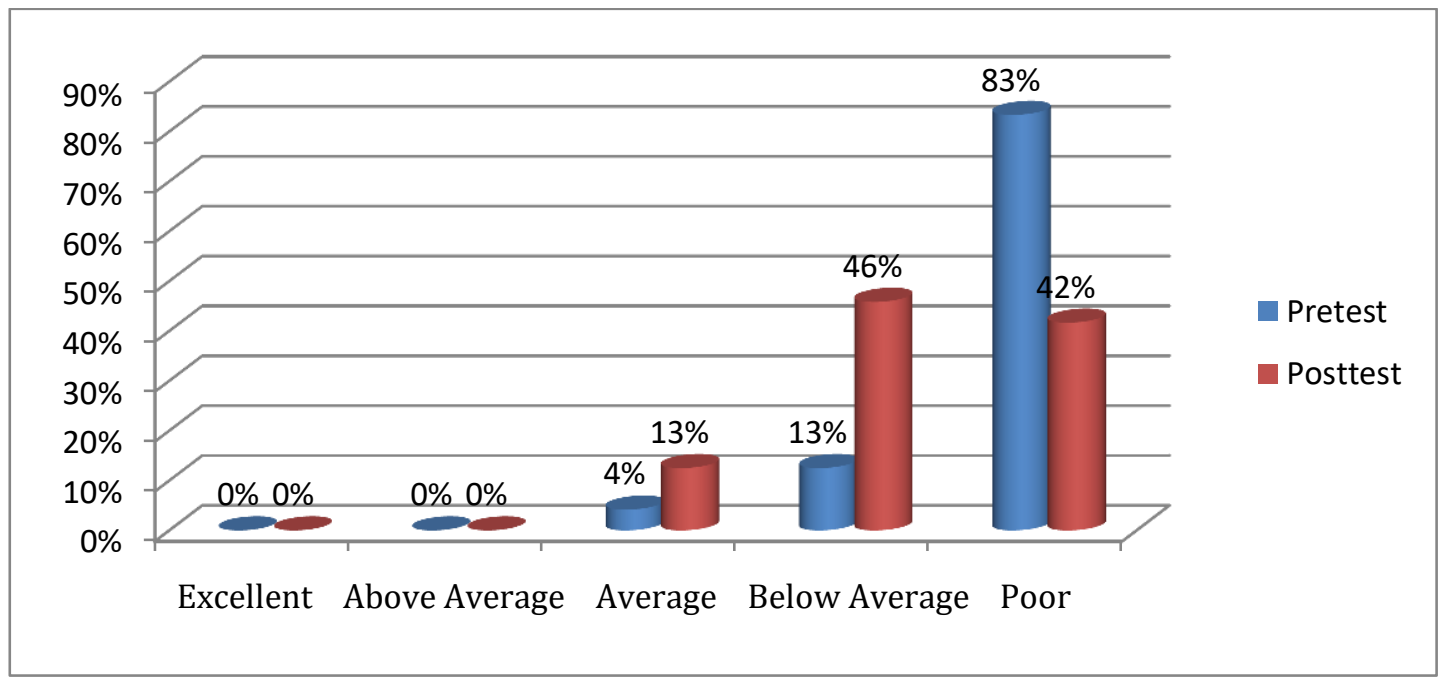

Figure 3.

Graph of Pretest and Posttest VO2 Max Practice Group Small-Sided Games 6 VS 6 
The Increase in $\mathrm{VO}_{2}$ Max and Passing Using Exercise Small-Sided Game 3 vs 3 and 6 vs 6 On Football Players Muhammad Fajri Maujud ${ }^{1 *}$,Zainal Afandi ${ }^{2}$, Budiman Agung Pratama ${ }^{3}$

Table 4.

Pretest and Posttest Results of Small-Sided Games 6 VS 6 Practice Group Passing

\begin{tabular}{cccccc}
\hline \multirow{2}{*}{ No } & \multirow{2}{*}{ Class Interval } & \multicolumn{2}{c}{ Pretest } & \multicolumn{2}{c}{ Posttest } \\
\cline { 2 - 6 } & & $\mathbf{F}$ & $\%$ & $\mathbf{F}$ & $\%$ \\
\hline 1 & $13-14$ & 0 & $0 \%$ & 5 & $21 \%$ \\
2 & $11-12$ & 2 & $8 \%$ & 10 & $42 \%$ \\
3 & $9-10$ & 5 & $21 \%$ & 8 & $33 \%$ \\
4 & $7-8$ & 11 & $46 \%$ & 0 & $0 \%$ \\
5 & $5-6$ & 6 & $25 \%$ & 1 & $4 \%$ \\
\hline & Total & $\mathbf{2 4}$ & $100 \%$ & 24 & $100 \%$ \\
\hline
\end{tabular}

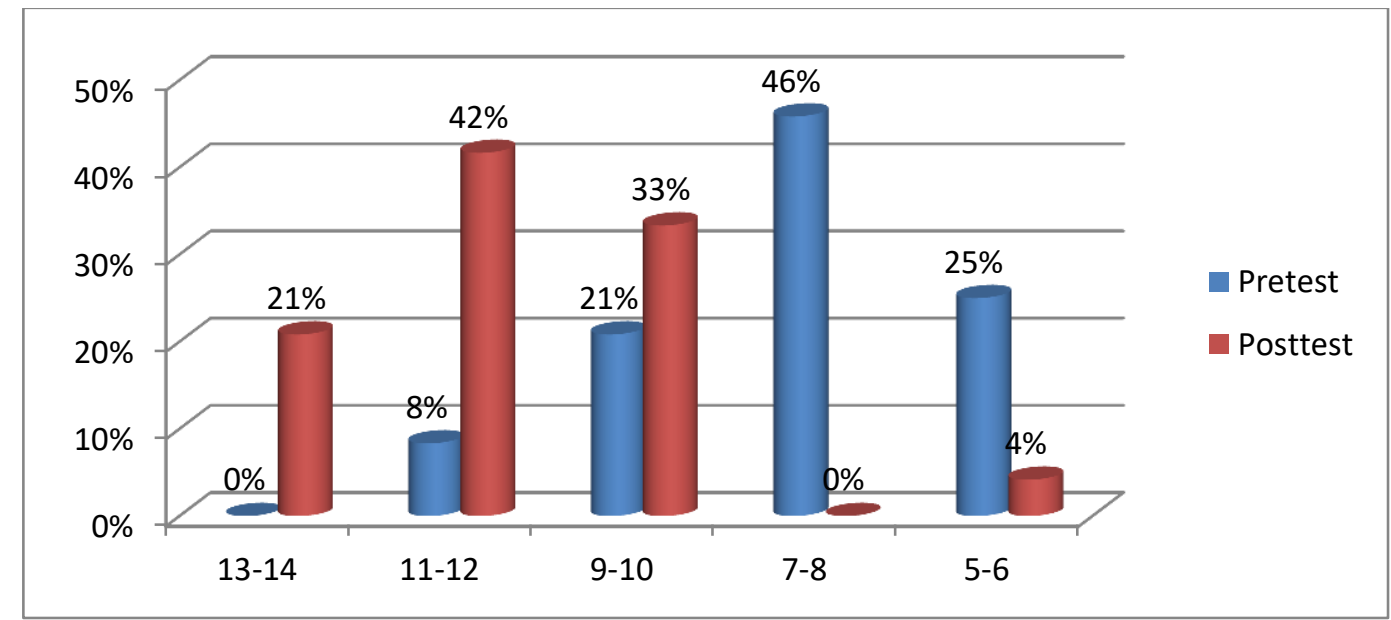

Figure 4.

Graph of Pretest and Posttest Passing Practice Small-Sided Games 6 VS 6

Tabel 5.

Manova Test Comparison of Posttest Results for Small-Sided Games 3 vs 3 and Small-Sided Games 6 vs 6 Against VO2Max Increase

\begin{tabular}{|c|c|c|c|c|}
\hline \multirow[b]{2}{*}{ Kelompok } & \multirow{2}{*}{ Rata-rata } & \multicolumn{3}{|c|}{ Tests of between-subjects effects } \\
\hline & & F-hitung & F-tabel & Sig \\
\hline Group ssg 3 vs 3 & 43,4917 & \multirow{2}{*}{4,662} & \multirow{2}{*}{2.80} & \multirow{2}{*}{0,031} \\
\hline Group ssg 6 vs 6 & 37,1833 & & & \\
\hline
\end{tabular}

Based on the Multivariate Analysis of Variance (MANOVA) test in Table 5, the posttest scores for Small-Sided games 3 vs 3 and the posttest small-sided games 6 vs 6 indicate that the sig value is $0.031<0.05$, so this result shows that there is a difference between the small-sided games 3 vs 3 exercise group and the small-sided games group sided games 6 vs 6 in VO2 max increase. 
The Increase in $\mathrm{VO}_{2}$ Max and Passing Using Exercise Small-Sided Game 3 vs 3 and 6 vs 6 On Football Players Muhammad Fajri Maujud $^{1^{*}}$, Zainal Afandi $^{2}$, Budiman Agung Pratama ${ }^{3}$

Table 6.

Manova Test Comparison of Posttest Results of Small-Sided Games 3 vs 3 and SmallSided Games 6 vs 6 Against Passing Improvement

\begin{tabular}{ccccc}
\hline Group & Rata-rata & \multicolumn{3}{c}{ Tests of between-subjects effects } \\
Group ssg 3 vs 3 & 11,8333 & F-hitung & F-tabel & Sig \\
Group ssg 6 vs 6 & 11,1250 & 4,868 & 2.80 & 0,027 \\
\hline
\end{tabular}

Based on the Manova test in Table 6, the posttest scores for Small-Sided games 3 vs 3 and the posttest Small-Sided games 6 vs 6 indicate that the sig value is $0.027<0.05$, so this result shows that there is a difference between the practice group for Small-Sided game 3 vs 3 and the Small-Sided games group. 6 vs 6 in increased passing. The results of this study indicate that overall small side game exercises 3 vs 3 and 6 vs 6 can increase vo2max. This is reinforced by research (Asmutiara, 2015) that Small-Sided game can increase the cardiovascular endurance of football players, using a small number of players will provide players play with high intensity that resembles a match in a competition, the main benefit of Small-Sided game as well as the replication of a real football game where the movement, intensity and technical play is similar to that of a competitive match so that it trains players to make decisions under pressure and fatigue due to the match (Hill-Haas et al. al., 2011). Besides being able to improve physical abilities, the results of this study also show that the small side game exercises 3 vs 3 and 6 vs 6 simultaneously can also improve passing technique skills, strengthening results of the study, some researchers also state that small side game exercises provide small side games. the effect on increasing football passing ability (Doewes, Purnama, Syaifullah, \& Nuryadin, 2020; Hakim, 2020).

In the 3 vs 3 Small-Sided game training group, the impact of changes for increasing vo2max, based on this the researcher can assume that the fewer number of players in the field will make the players perform more performance during training, following other research that in Small-Sided games training 4 vs 4 players cover more distances and sprint more often than 11 vs 11 exercises (Dellal et al., 2012), but in the 6 vs 6 SmallSided games training group with more players, the intensity of training will be higher. not too high compared to the 3 vs 3 Small-Sided games training for junior athletes, following other research that with the advantages and disadvantages of 6 vs 6 and 3 vs 3 Small- 
The Increase in $\mathrm{VO}_{2}$ Max and Passing Using Exercise Small-Sided Game 3 vs 3 and 6 vs 6 On Football Players

Muhammad Fajri Maujud ${ }^{1 *}$,Zainal Afandi ${ }^{2}$, Budiman Agung Pratama ${ }^{3}$

Fajrimaujud46@gmail.com

Sided games training, coaches can determine the type of exercise needed for their athletes (Silva, 2014).

\section{CONCLUSIONS AND SUGGESTIONS}

This study concludes that overall small side game exercises 3 vs 3 and 6 vs 6 can increase vo2max and passing for U-14 football players. For coaches, it can be a source of knowledge, motivation, and evaluation material of an exercise program to train and improve VO2 max ability and passing skills using Small-Sided games 3 vs 3 and SmallSided games 6 vs 6 . Suggestions for further research are research on the performance analysis of junior athletes using Small-Sided games 3 vs 3 and Small-Sided games 6 vs 6 .

\section{REFERENCES}

Apriliyanto, R. (2019). Pengaruh Pelatihan Small-Sided Games terhadap Peningkatan Kapasitas Aerobik Maksimal dan Keterampilan Dribbling pada Pemain Sepakbola. Biormatika: Jurnal ilmiah fakultas keguruan dan ilmu pendidikan, 5(01), 5664. https://doi.org/10.35569/biormatika.v5i01. 414

Asmutiara, A. (2015). Pengaruh Pelatihan Small-Sided Games Three-A-Sided Dan Small-Sided Games Six-A-Sided Terhadap Peningkatan Cardiovascular Endurance Pemain Sepakbola. Jurnal Pendidikan Olahraga, 4(2). https://dx.doi.org/10.31571/jpo.v4i2.82

Dellal, A., Owen, A., Wong, D., Krustrup, P., Van Exsel, M., \& Mallo, J. (2012). Technical and physical demands of small vs. large sided games with playing position in elite soccer. Human movement science, 31(4), 957-969. https://doi.org/10.1016/j.humov.2011.08.013

Doewes, R. I., Purnama, S., Syaifullah, R., \& Nuryadin, I. (2020). The Effect of SmallSided Games Training Method on Football Basic Skills of Dribbling and Passing in Indonesian players aged 10-12 years. Int J Adv Sci Technol, 29(3), 429-441. http://sersc.org/journals/ index .php/IJAST/article/view/ 5620

Hakim, L. (2020). Pengaruh Latihan Small Side Game Terhadap Keterampilan Passing Siswa Smp Plus Nurul Huda Dalam Ekstrakurikuler Sepak Bola Tahun Ajaran 2020. utile: Jurnal Kependidikan, 6(2), 137-145. https://doi.org/10.37150/jut.v6i2.996

Hill-Haas, S. V., Dawson, B., Impellizzeri, F. M., \& Coutts, A. J. (2011). Physiology of small-sided games training in football. Sports medicine, 41(3), 199-220. $10.2165 / 11539740-000000000-00000$ 
The Increase in $\mathrm{VO}_{2} \mathrm{Max}$ and Passing Using Exercise Small-Sided Game 3 vs 3 and 6 vs 6 On Football Players

Muhammad Fajri Maujud ${ }^{1 *}$,Zainal Afandi ${ }^{2}$, Budiman Agung Pratama ${ }^{3}$

Fajrimaujud46@gmail.com

Katis, A., \& Kellis, E. (2009). Effects of small-sided games on physical conditioning and performance in young soccer players. Journal of sports science \& medicine, 8(3), 374. https://www.ncbi.nlm.nih.gov/pmc/articles/PMC3763282/

Kelly, D. M., \& Drust, B. (2009). The effect of pitch dimensions on heart rate responses and technical demands of small-sided soccer games in elite players. Journal of Science and Medicine in Sport, 12(4), 475-479. 10.1016/j.jsams.2008.01.010

Maksum, A. (2012). Metodologi penelitian dalam olahraga: Surabaya: Unesa University Press.

Owen, A., Twist, C., \& Ford, P. (2004). Small-sided games: the physiological and technical effect of altering pitch size and player numbers. Insight, 7(2), 50-53. https://www.research gate .net/ publication/233799837

Pratama, B. A. (2017). Effectiveness of shooting training model based drill of shooting product in youth soccer. International Journal of Physiology, Nutrition and Physical Education 2 (2), 313-316 https://www.journalofsports.com/archives /2017/vol2/issue2/2-2-52

Putra, A. U. K. (2015). Pengaruh Latihan Small-Sided Games Terhadap Peningkatan Kemampuan Vo2max Pemain Sepakbola Di Persatuan Sepakbola Smuba Junior Kota Batu. SKRIPSI Jurusan Pendidikan Jasmani dan Kesehatan-Fakultas Ilmu Keolahragaan Universitas Negeri Malang.

Shandy, D. K. (2017). Perbedaan Pengaruh Latihan Small-Sided Games Type intermitten dan Continou Terhadap Kapasitas Aerobik Pemain Sepakbola Indonesia Muda Kabupaten Lamongan. SKRIPSI Jurusan Pendidikan Jasmani dan Kesehatan-Fakultas Ilmu Keolahragaan Universitas Negeri Malang.

Silva, B., Garganta, J., Santos, R., \& Teoldo, I. . (2014). Comparing Tactical Behaviour of Soccer Players in 3 vs. 3 and 6 vs. 6 Small-Sided Games. Journal of human kinetics, 41, 191-2002. 10.2478/hukin-2014-0047

Wahyudianto, M. Z., Setiawan, I., \& Pratama, B. A. (2020). Pengaruh Latihan Small Side Game Tipe Intermitten Terhadap Kapasitas Aerobik Di Sekolah Sepakbola Satria Muda Lamongan. SPRINTER: Jurnal Ilmu Olahraga, 1(1), 72-78. https://jurnal.icjambi.id/ index.php/sprinter/ article/view/40

Winarno, M. (2006). Tes Keterampilan Olahraga. Malang: Laboratorium Jurusan Ilmu Keolahragaan Fakultas Ilmu Pendidikan Universitas Negeri Malang. 